\title{
Synthesis, Metal Ions Coordination, Antimicrobial Activity of Some $L$-Tartaric Acid Derivatives
}

\author{
ZOULIKHA KHIATI, ABDELHAK CHERCHAR and ADIL A OTHMAN*
}

Laboratory of Bioactive Organic Chemistry-LCOB-, Department of Chemistry, Faculty of Science, University of Science and Technology-Mohamed Boudiaf-Oran, USTO-MB.B.P.1505 ElMnaouer, 31000, Oran, Algeria

adilaliothman@yahoo.ca

Received 7 May 2012 / Accepted 17 May 2012

\begin{abstract}
The bis-1,3,4-oxadiazole-thione and bis-4-amino-1,2,4-triazole-thiol derivatives from $L$-tartaric acid were synthesized. The synthetic intermediates, ester, hydrazide and oxadiazole derivatives have shown a significant tendency to form complexes with $\mathrm{Fe}(\mathrm{III}), \mathrm{Ni}(\mathrm{II})$ and $\mathrm{Cu}(\mathrm{II})$ ions. The formation of complexes with metals was detected by UV-Vis and IR spectroscopy. A novel complex nucleoside from bis-4-amino-1,2,4-triazole-thiol derivative with l-arabinose was also synthesized. The antimicrobial activity for final and synthetic intermediates in vitro against the microorganisms: Escherichia coli, Pseudomonas aeruginosa, Yersinia pseudotuberculosis, Enterococcus faecalis, Staphylococcus aureus and Candida albicans were examined and some products showed noticeable activity against the tested microorganisms.
\end{abstract}

Keywords: 1,3,4-Oxadiazole-thione, 1,2,4-Triazole-thiol, L-Tartaric acid, Antimicrobial activity, Complex formation

\section{Introduction}

Tartaric acid occurs naturally in many plants, particularly grapes, bananas and tamarinds. It is added to food to give a sour taste ${ }^{1}$ and is used as an antioxidant ${ }^{2}$. Tartaric acid is a muscle toxin, which works by inhibiting the production of malic acid and in high doses causes paralysis and death ${ }^{3}$. It is used in the medical fields ${ }^{4}$ and acting as a preservative after fermentation $^{5}$. Salts of tartaric acid (Rochelle salt) used as mild laxative and tartaric dihydrazides utilized as agrochemicals ${ }^{6}$. Derivatives of tartaric acid are frequently used, widely available and inexpensive acid resolving agents for the separation of racemic mixtures via diastereoisomeric salt ${ }^{7,8}$ or supramolecular compound formations ${ }^{9,10}$. Tartaric acid and its derivatives such as: esters, hydrazides, 1,3,4-oxadiazole-2-thiones and 1,2,4-triazole thiols can be ideal ligands to build up organo-matallic complexes ${ }^{11,12}$. In another hand, tartaric acid may be used as good starting material for the synthesis of doubleheaded nucleosides and studying their antimicrobial activity.

It is well documented that 1,3,4-oxadiazole, 1,2,4-triazole and their thiol derivatives are classes of heterocyclic, known to show a wide variety of biological ${ }^{13-15}$ and industrial applications ${ }^{16,18}$. Also, tying up of sugar molecules to simple heterocyclic moieties are often employed to deal with targeting mechanism of action and /or pharmacology ${ }^{19}$. Although 
mono-nuclear bases such as oxadiazole and triazole derivatives linked to a glycofuranose and/ or glucopyranose skeleton have been described in the literature ${ }^{20}$ but little information about double headed nucleosides were published ${ }^{2}$.

The growing attention in the chemistry of double-headed nucleosides in the literature and tendency of metal-complex formation prompted us to design the synthesis of some $L$-tartaric acid derivatives such as bis-oxadiazole and bis -4-amino triazole. For the purpose of evaluating their capacity to form metal ion complexes and biological activity against Gram-positive and Gram-negative bacteria and fungus.

\section{Experimental}

All reactions were monitored by TLC silica gel $60 \mathrm{~F}_{254}$, Merck, Germany. The melting points were measured with a BÜCHI 540 melting point apparatus and are uncorrected. The IR spectra were recorded using $\mathrm{KBr}$ discs and a JASCO V-530 spectrophotometer and in the IR spectra solutions were obtained with a GENESIS II FTIR spectrophotometer. The UV-VIS spectra were recorded by UV-VIS Spectrophotometer 4418 PC (ZUZI). The ${ }^{1} \mathrm{H}$, ${ }^{13} \mathrm{C}$ NMR $\left(250 \mathrm{MHz}\right.$ ) spectra were recorded on Bruker AC $250 \mathrm{MHz}$ in $\mathrm{CDCl}_{3}$ and referenced to TMS. Bacterial evaluations were performed in the Department of Chemistry, University of Alexandria, Egypt.

\section{Synthesis}

\section{Diethyl - I (+)-tartarate (2) [L1]}

$L(+)$ tartaric acid (1, $1.5 \mathrm{~g}, 0.01$ mole), ethanol $(10 \mathrm{~mL})$ and sulphuric acid $(1.0 \mathrm{~mL})$ were refluxed in an oil bath $110{ }^{\circ} \mathrm{C}$ for 7 hours. Aqueous brine solution (15 mL) was added and stirred then allowed to stand for few minutes, neutralized with sodium bicarbonate solution to $\mathrm{pH}=7$, extracted three times with dichloromethane $(10 \mathrm{~mL})$, dried over anhydrous $\mathrm{Na}_{2} \mathrm{SO}_{4}$ and filtered. Dichloromathane was evaporated down to dryness to give colourless syrup of diethyl - $L(+)$-tartarate (2, 1.43 g, 96\%). For UV spectrum, see Table 1 and for IR spectrum (Table 2).

\section{L (+)Tartaric dihydrazides (3) [L2]}

Diethyl - $L(+)$ tartarate (2, $5.0 \mathrm{~g}, 0.025$ mole), ethanol (35 mL) and hydrazine hydrate 64\% $(20 \mathrm{~mL}$ ) were mixed at room temperature for 25 minutes. A white crystalline precipitate was formed, filtered, washed with cold ethanol and recrystallized from water/ethanol gave L $(+)$ tartaric dihydrazides (3, 4.2 g, 84\%), m.p 178-180 ${ }^{\circ} \mathrm{C}$. For U.V. spectrum, see Table 1 and for IR spectrum, see Table 2.

\section{Bis-1,3,4-oxadiazole-5-thionylethylene glycol (4) [L3]}

Dihydrazide- $L(+)$-tartarate (3, $5.0 \mathrm{~g}, 0.028 \mathrm{~mole}$ ) was dissolved in water (30 mL), aqueous solution of $\mathrm{KOH}$ ( $\mathrm{KOH} 10 \mathrm{~g}$ in water $10 \mathrm{~mL}$ ) and carbon disulphide $(80 \mathrm{~mL}$ ) was added and the mixture was refluxed at $110^{\circ} \mathrm{C}$ for $4 \mathrm{~h}$. After cooling, $\mathrm{HCl}(30 \%)$ was added drop wise until $\mathrm{pH}=5$, solid formed and filtered. The solid was washed with cold acetone, recrystallized from ethanol/chloroform to give colorless fibers of (4, 3.6 g, 72\%), m.p. 240-242 ${ }^{\circ} \mathrm{C}$. For UV spectrum Table 1 and IR spectrum Table $2 .{ }^{1} \mathrm{H}$ NMR $(250 \mathrm{MHz}$, DMSO- $\left.d_{6}\right), \delta_{\mathrm{H}} 8.90(\mathrm{~s}, 2 \mathrm{H}, 2-\mathrm{NH}), 4.31(\mathrm{~s}, 1 \mathrm{H}, \mathrm{OH}), 4.21$ (s, 1H, OH), 3.92 (d, 1H, C-1-H or C-2-H), 3.73 (d, 1H, C-2-H or C-1-H), 3.57 (s, 1H, SH), 3.3 (s, 1H, SH). ${ }^{13} \mathrm{C}$ NMR (250 MHz, DMSO-d $\left.\mathrm{d}_{6}\right), \delta_{\mathrm{C}} 173.18(\mathrm{C}=\mathrm{S}), 151.88(\mathrm{C}=\mathrm{N}), 73.11(\mathrm{C}-1), 65.98(\mathrm{C}-2)$. Calculated for $\mathrm{C}_{6} \mathrm{H}_{6} \mathrm{~N}_{4} \mathrm{O}_{2} \mathrm{~S}_{2}$, C, 31.30\%, H, 02.61\%, N, 24.35\%. Found: C, 31.54\%, H, 02.59\%, N, 24.05\%. 
Bis-(4-amino-5-mercapto-4H-1, 2, 4-triazole-3-yl) ethylene glycol (5)

Dihydrazide- $L(+)$ tartarate (3, 5.0 g, 0.028 mole) was dissolved in alcoholic $\mathrm{KOH}(\mathrm{KOH}$ $1.5 \mathrm{~g}$ in methanol $35 \mathrm{~mL})$ added to it carbon disulphide $(10 \mathrm{~mL})$, the mixture was magnetically stirred for $17 \mathrm{r}$ at room temperature. Dichloromethane $(20 \mathrm{~mL})$, hydrazine hydrate $67 \%(10 \mathrm{~mL}), \mathrm{KCl}(2.0 \mathrm{~g})$ in water $(20 \mathrm{~mL})$ were gradually added and the reaction mixture was refluxed for $4 \mathrm{~h}$ at which hydrogen sulphide gas was evolved and the colour of the solution had changed into bright green. The reaction mixture was cooled down to room temperature, $\mathrm{HCl}$ was added to $\mathrm{pH}=1$. The precipitate formed, filtered, washed with $\mathrm{H}_{2} \mathrm{O}$ and recrystallized from ethanol to give colorless crystalline 5 (3.5 g, 70\%), m.p. $122{ }^{\circ} \mathrm{C}$. IR $(\mathrm{KBr}) \mathrm{cm}^{-1}: 3422.7(\mathrm{OH}), 3330(\mathrm{NH}), 2800(\mathrm{SH}), 1605(\mathrm{C}=\mathrm{N}), 1406(\mathrm{C}=\mathrm{S}) .{ }^{1} \mathrm{H}-\mathrm{NMR}$ $\left(\mathrm{CDCl}_{3}\right), \delta$ ppm: $9.6\left(\mathrm{~s}, 2 \mathrm{H}, \mathrm{NH}_{\text {aromatic }}\right), 4.8\left(\mathrm{~s}, 4 \mathrm{H}, \mathrm{NH}_{2}\right), 4.6(\mathrm{~s}, \mathrm{H}, \mathrm{OH}), 4.5(\mathrm{~s}, \mathrm{H}, \mathrm{OH}), 2.85$ (s, 2H, SH), 2.4 (d, 2H, C-H) ${ }^{13} \mathrm{C}-\mathrm{NMR}\left(\mathrm{CDCl}_{3}\right), \delta$ ppm: $206.38(\mathrm{C}=\mathrm{S}), 180(\mathrm{C}-\mathrm{SH}), 147.9$ $(\mathrm{N}=\mathrm{C}-\mathrm{N}), 74.23$ and $72(\mathrm{C}-\mathrm{OH}) .{ }^{19}$ Calculated for $\mathrm{C}_{6} \mathrm{H}_{10} \mathrm{~N}_{8} \mathrm{O}_{2} \mathrm{~S}_{2}, \mathrm{C}, 24.83 \%, \mathrm{H}, 03.45 \%, \mathrm{~N}$, $38.62 \%$. Found: C, 25.03\%, H, 03.54\%, N, 38.54\%.

Bis-(4-L(+)-arabinosidyl-amino-5-mercapto-4H-[1,2,4]-triazole-3-yl)ethylene glycol (6)

Amino triazole (5, $1.5 \mathrm{~g}, 0.005$ mole), L(+)-arabinose (1.75 g, 0.01 mole), ethanol (25 mL) and $\mathrm{HCl}(0.5 \mathrm{~mL})$ were mixed together and refluxed for $4 \mathrm{~h}$. The reaction mixture was neutralized with $\mathrm{NaHCO}_{3}$; fine powder was formed and filtered. The filtrate concentrated to half volume to give more fine precipitate, combined batches of 6 (1.13 g, 75.33\%) changed into yellow syrup by standing. IR $(\mathrm{KBr}) \mathrm{cm}^{-1}$ : $36312(\mathrm{OH}), 3334(\mathrm{NH}), 2884(\mathrm{SH})$. Calculated for $\mathrm{C}_{16} \mathrm{H}_{26} \mathrm{~N}_{8} \mathrm{O}_{10} \mathrm{~S}_{2}, \mathrm{C}, 34.66 \%, \mathrm{H}, 04.69 \%$, N, 20.22\%. Found: C, $35.00 \%$, $\mathrm{H}, 04.99 \%$ and $\mathrm{N}, 19.99 \%$.

\section{Complex formation}

\section{General Procedure of 1:1 stoichoimetric ligands-metal complexation}

The ligand (1.0 mole) dissolved in ethanol/water, metal chloride (1.0 mole) in ethanol/water were mixed together. An immediate precipitate was formed. The reaction mixture was allowed to stir magnetically for overnight at room temperature. Filtered and washed with cold ethanol. The filtrate concentrated to half volume to give more fine precipitate, combined batches of Lx-M (1.13 g, 75\%). For U.V. spectrum refer Table 1 and for IR spectrum refer Table 2.

Antimicrobial activity

A disk diffusion assay according to the standard protocols (NCCLS, 2003, 2005; CLSI, 2006) were used ${ }^{22-24}$ to determine the susceptibility of three Gram-positive bacteria Staphylococcus aureus ATCC 25923 and Enterococcus faecalis ATTC 29212 and two Gram-negative bacteria Escherichia coli ATCC 25924, Pseudomonas aeruginosa ATCC 10145 and fungus C. albicans using Ampicillin and Gentamycin as references. The bacterial suspension (in $0.9 \% \mathrm{NaCl}$ ) turbidity were adjusted to $0.5 \mathrm{McF}$ arland, then the suspensions were spread with a sterile cotton swab confluently over the entire surface of Mueller Hinton agar (Merck, Germany).

\section{The minimum inhibition concentration (MIC) tests}

Each $1 \mathrm{~mL}$ of the original concentration $\left(10 \mu \mathrm{g} \mathrm{mL}^{-1}\right)$ in DMSO $(10 \% \mathrm{v}: \mathrm{v})$ of the compounds 2-6 were diluted with DMSO for five times to 5.0, 2.5, $1.25 \mu \mathrm{g} \mathrm{mL}^{-1}$ and optical density were measured at $600 \mathrm{~nm}$ at $0,18,24$ and $48 \mathrm{~h}$. 


\section{Results and Discussion}

\section{Synthesis and characterization of ligands}

The bis-1, 3, 4 -oxadiazole-2(3H) - thionyl ethylene glycol 4 and bis- 1, 2, 4-triazole-3(4H)thiolyl ethylene glycol 5 have been obtained by three steps synthesis from $\mathrm{L}(+)$-tartaric acid according to scheme 1. Diethyl tartarate 2 was isolated in excellent yield (96\%) from the parent tartaric acid.

The ester $\mathbf{2}$ was treated with hydrazine hydrate (64\%) to give dihydrazide $\mathbf{3}$ in very good yield (84\%). The oxadiazole 4 was obtained by treating 3 with carbon disulphide in presence of slight excess of aqueous $\mathrm{KOH}$ in ethanolic medium. IR spectrum of $\mathbf{4}$ exhibited strong bands at 3442, 3350 and $3238 \mathrm{~cm}^{-1}$ for free and bonded $\mathrm{OH}$ groups in addition there were two weak bands observed at 2480 and $2428 \mathrm{~cm}^{-1}$ assigned to two SH groups. The IR also showed a strong band at $1637 \mathrm{~cm}^{-1}$ was assigned to $\mathrm{C}=\mathrm{N}$ bond ${ }^{8}$ and two bands at 1468 and $1412 \mathrm{~cm}^{-1}$ attributed to $\mathrm{C}=\mathrm{S}$ groups in two oxadiazole thione rings. The spectrum also exhibited absorptions at 1120 and $1105 \mathrm{~cm}^{-1}$ were assigned to $\mathrm{N}-\mathrm{N}$ bonding in two oxadiazole rings $^{25}$. These observations suggested that oxadiazole exists in the thione form 4 in solid form with a trace of the thiol form. The 4- $N$-amino- $4 H-1,2,4-$ triazole derivative 5 was obtained from the dihydrazide 3 by refluxing the latter with carbon disulphide and hydrazine hydrate. The product 5 had shown the characteristic bands in IR, $3422(\mathrm{OH}), 3330$ $(\mathrm{NH}), 2800(\mathrm{SH}), 1608(\mathrm{C}=\mathrm{N})$ and $1406(\mathrm{C}=\mathrm{S})$. The vibration absorption bands of the triazole framework 943, 692 and $586 \mathrm{~cm}^{-1}$ were also present ${ }^{27}$. The presence of SH band is the primary indication for the formation of the triazole and exhibiting the known thione-thiol tautomeric phenomenon which is usually associated with this structural system.

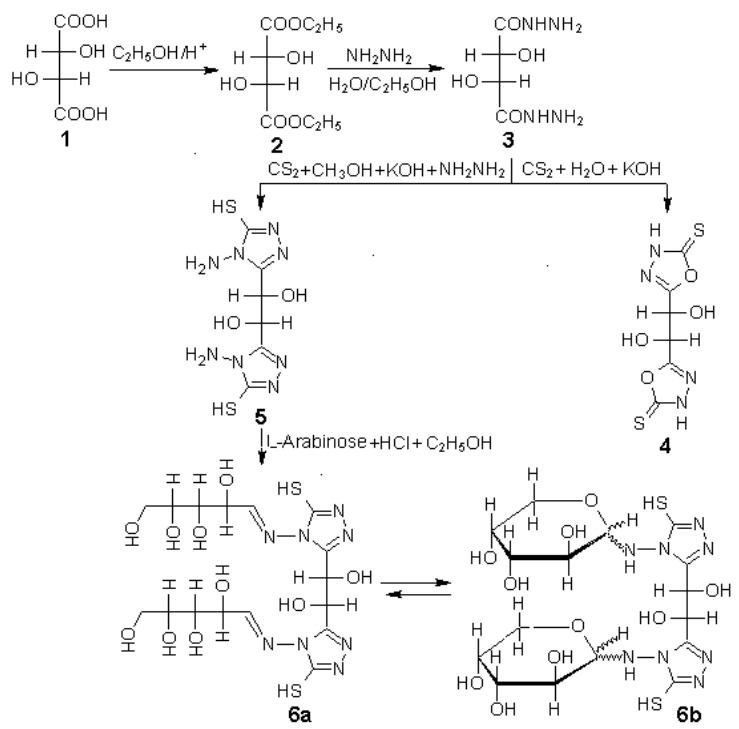

Scheme 1. The general synthetic pathway of 4, 5 and 6

The ${ }^{1} \mathrm{H}-\mathrm{NMR}$ spectrum of $\mathbf{5}$ exhibited the $\mathrm{NH}_{2}$ signal at $4.8 \mathrm{ppm}$ and another signal at $9.6 \mathrm{ppm}$ for aromatic $\mathrm{NH}$ within the triazole ring. The ${ }^{13} \mathrm{C}-\mathrm{NMR}$ spectrum exhibited signals at $206 \mathrm{ppm}$ attributed to $\mathrm{C}=\mathrm{S}, 180 \mathrm{ppm}$ assigned for $\mathrm{C}-\mathrm{SH}$ and at 74 and $72 \mathrm{ppm}$ related to acyclic carbons linked to $\mathrm{OH}$. IR, ${ }^{1} \mathrm{H}-\mathrm{NMR}$ and ${ }^{13} \mathrm{C}$-NMR spectra indicating that the amino triazole $\mathbf{5}$ is existed as mixture of thione and thiol form. 
The condensation of $\mathbf{5}$ with $L$-arabinose in ethanol in presence of $\mathrm{HCl}$ gave the glycoside 6 in good yield (75\%). IR showed the characteristic bands at $3613(\mathrm{OH}), 3334$ (NH), $2359(\mathrm{SH}) \mathrm{cm}^{-1}$. This indicates that condensation had occurred with $4-N$-amino group to give theoretically the structure $\mathbf{6 a}$ which substantially cyclized preferably into pyranoside 6b and/or less probable in furanoside ring. ${ }^{1} \mathrm{H}-\mathrm{NMR}$ confirmed this by the presence of a signal at $2.1 \mathrm{pp}$. attributed to $\mathrm{SH}$.

\section{Synthesis and characterization of complexes}

The compounds 2, 3 and 4 will be assigned as ligand 1 (L1), ligand 2 (L2) and ligand 3 (L3) respectively for the purpose of complex formation. The ligands L1, L2 and L3 complexes with trivalent ion $\mathrm{Fe}(\mathrm{III})$ and divalent ions $\mathrm{Cu}(\mathrm{II})$ and $\mathrm{Ni}$ (II) were prepared according to the literature by using appropriate solvents ${ }^{28}$. Ethyl tartarate 2 (L1) dissolved in ethanol while the other ligands, dihydrazide 3 (L2) and bis-oxadiazole 4 (L3) were soluble in water. Formation of complexes between L1, L2, L3 and ions $\mathrm{Fe}(\mathrm{III}), \mathrm{Ni}(\mathrm{II})$ and $\mathrm{Cu}(\mathrm{II})$ were associated with changes in colors (see Table 1). The electronic spectra of L1-Fe, L1-Ni and L1-Cu displayed shifts from $223 \mathrm{~nm}(\mathbf{L 1})$ to $416 \mathrm{~nm}, 404 \mathrm{~nm}$ and $403 \mathrm{~nm}$ respectively. L2-Fe, L2-Ni and L2-Cu showed shifts from $230 \mathrm{~nm}(\mathbf{L 2})$ to $545 \mathrm{~nm}, 386$ and $405 \mathrm{~nm}$ respectively. While L3-M complexes showed shifting in absorption maxima from $288 \mathrm{~nm}, 342 \mathrm{~nm}$ and $379 \mathrm{~nm}$ (L3) to $503 \mathrm{~nm}$ (for L3-Fe), $569 \mathrm{~nm}$ (L3-Ni) and $413 \mathrm{~nm}$ (for L3-Cu) as shown in Table 1.

Table 1. M.P., UV /Vis. Maxima and colour of ligands L1, L2, L3 and their complexes with $\mathrm{Fe}(\mathrm{III}) \mathrm{Ni}(\mathrm{II})$ and $\mathrm{Cu}(\mathrm{II})^{\dagger}$

\begin{tabular}{llcll}
\hline Compound & \multicolumn{1}{c}{ L1 } & L1/Fe & \multicolumn{1}{c}{ L1/Ni } & L1/Cu \\
\hline M.P ${ }^{\circ} \mathrm{C}$ & 12 & $>360$ & $>360$ & $>360$ \\
U.V./Vis. & $223(2.518)$ & $448(0.825)$ & $394(0.022)$ & $403(0.934)$ \\
$\lambda_{\max } \mathrm{nm}$ & & $525(0.597)$ & $660(0.091)$ & $815(0.895)$ \\
$(\log \varepsilon)$ & & $964(0.184)$ & $730(0.010)$ & $959(0.791)$ \\
& & & $975(0.020)$ & \\
Colour & Colorless & Brown & Dark-green & Green \\
\hline Compound & L2 & L2/Fe & L2/Ni & L2/Cu \\
\hline M.P ${ }^{\circ} \mathrm{C}$ & $178-180$ & $>360$ & $>360$ & $>360$ \\
U.V./Vis. & $230(2.971)$ & $545(0.065)$ & $386(0.073)$ & $814(0.246)$ \\
$\lambda_{\max } \mathrm{nm}$ & & $966(0.003)$ & $654(0.097)$ & $405(0.273)$ \\
$($ Log $\varepsilon)$ & & & $736(0.135)$ & $630(0.187)$ \\
& & & $1068(0.204)$ & \\
Colour & Colorless & Brown & Blue & Green \\
\hline Compound & L3 & L3/Fe & L3/Ni & L3/Cu \\
\hline M.P ${ }^{\circ} \mathrm{C}$ & $240-242$ & $>360$ & $>360$ & $>360$ \\
U.V./Vis. & $288(1.739)$ & $503(0.321)$ & $659(0.042)$ & $413(0.634)$ \\
$\lambda_{\max }$ nm & $342(3.192)$ & $985(0.026)$ & $734(0.038)$ & $982(0.047)$ \\
$($ Log $\varepsilon)$ & $379(2.340)$ & & $989(0.049)$ & \\
Colour & Pale-yellow & Dark-brown & Dark-green & Yellow-brown \\
\hline
\end{tabular}

${ }^{\dagger} U$.V. maxima in $\mathrm{nm}$ (Log e) and colors for salts: $\mathrm{FeCl}_{3}, 416$ (2.959), yellow; $\mathrm{NiCl}_{2}, 404$ (0.023), green; $\mathrm{CuCl}_{2}$, blue-green,868(0.700)

These results are in accord with reported observations of great affinity of ions $\mathrm{Ni}$ and $\mathrm{Cu}$ to form complexes with nitrogen, oxygen and sulphur atoms ${ }^{29}$. All complexes displayed strong peaks between $300 \rightarrow 570 \mathrm{~nm}$ due to charge transfere and inter ligand electronic transition. The other peaks at $600 \rightarrow 750 \mathrm{~nm}$ are assigned reasonably to ${ }^{2} \mathrm{E}_{\mathrm{g}} \rightarrow{ }^{2} \mathrm{E}_{2 \mathrm{~g}}$ transition $^{30,31}$. 
A supporting proof for the formation of complexes can be observed from infrared spectroscopy. The IR spectra (Table 2) provide useful information regarding the stereochemistry and the nature of functional group(s) attached to the metal ions. The strongest $\mathrm{OH}$ stretching bands for the ligands $\mathbf{L 1}, \mathbf{L} \mathbf{2}$ and $\mathbf{L 3}$ are displayed in the positions $3444.24 \mathrm{~cm}^{-1}, 3409.53 \mathrm{~cm}^{-1}$ and $3442.31 \mathrm{~cm}^{-1}$ respectively.

Table 2. IR spectral bands position/ $\mathrm{cm}^{-1}$ of the ligands $\mathbf{L 1}, \mathbf{L 2}, \mathbf{L} 3$ and their complexes with Fe-III), Ni(II) and Cu(II) ions

\begin{tabular}{|c|c|c|c|c|c|c|c|}
\hline Compounds & $\gamma(\mathrm{OH})$ & $\gamma(\mathrm{NH})$ & $\gamma(\mathrm{SH})$ & $\gamma(\mathrm{C}=\mathrm{O}$ & $\gamma(\mathrm{C}=\mathrm{N})$ & $\gamma(\mathrm{C}=\mathrm{S})$ & $\gamma(\mathrm{N}-\mathrm{M})$ \\
\hline L1 & 3444.24 & & & 1747.19 & & & \\
\hline L1-Fe(III) & 3397.96 & & & 1739.48 & & & \\
\hline L1-Ni(II) & 3400.00 & & & 1741.41 & & & \\
\hline L1-Cu(II) & 3444.24 & & & 1737.55 & & & \\
\hline \multirow[t]{3}{*}{ L2 } & 3409.53 & 3357.46 & & 1664.27 & & & \\
\hline & & 3313.11 & & & & & \\
\hline & & 3286.11 & & & & & \\
\hline L2-Fe(III) & $3500.00(w)$ & 3241.75 & & 1700.91 & & & 491.75 \\
\hline L2-Ni(II) & $3520.00(w)$ & 3228.25 & & 1680.77 & & & 455.12 \\
\hline L2-Cu(II) & $3530.00(w)$ & 3230.18 & & 1698.98 & & & 466.68 \\
\hline \multirow[t]{2}{*}{ L3 } & 3442.31 & 3349.9 & 2480.01(m) & & 1637.27 & 1467.56(s) & \\
\hline & & 3237.9 & & & & 1411.64(m) & \\
\hline \multirow[t]{2}{*}{ L3-Fe(III) } & $3500.00(w)$ & 3367.10 & 2400.94(w) & & 1648.84 & $1490.70(w)$ & 470.00 \\
\hline & & & & & & $1380(\mathrm{~S})$ & \\
\hline \multirow[t]{2}{*}{ L3-Ni(II) } & $3520.00(w)$ & 3370.96 & & & 1617.98 & $1490.00(\mathrm{~m})$ & 488.83 \\
\hline & & & & & & $1390.42(\mathrm{~s})$ & \\
\hline \multirow[t]{2}{*}{ L3-Cu(II) } & $3500.00(w)$ & 3226.33 & & & 1639.2 & 1402.92(m) & 455.4 \\
\hline & & & & & & $1361.5(\mathrm{~s})$ & \\
\hline
\end{tabular}

This indicating that the $\mathrm{OH}$ groups of the ligands are more bonded by intramolecular hydrogen bonding which preferring an eclipse glycol form (Figure 1). While the $\mathrm{OH}$ absorption for the metal complexes are appearing at higher regions $3500-3520 \mathrm{~cm}^{-1}$.<smiles></smiles>

Figure 1. Intramolecular hydrogen in eclipsed form of glycol moiety

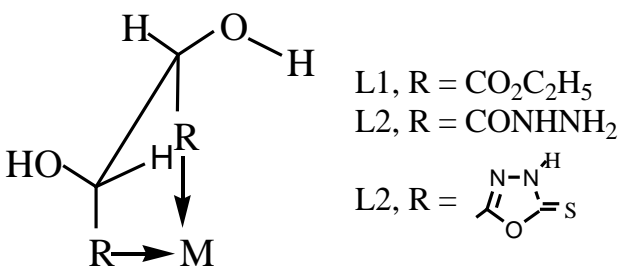

Figure 2. Staggered form of glycol moiety in Lx-M complexes

This suggesting that complex formation is taking place between the carbonyl groups in the ester $\mathbf{2}$, the hydrazide $\mathbf{3}$ and the oxadiazole-thiol $\mathbf{4}$ rings with the metal ions as in Figure 2. In $\mathbf{L 1}$ the value of $\gamma(\mathrm{C}=\mathrm{O})$ stretching vibration is displayed in $1747 \mathrm{~cm}^{-1}$ while in $\mathbf{L 1 - F e}$ it appears at a lower region $1739 \mathrm{~cm}^{-1}$, in $\mathbf{L 1 - N i}$ at $1741 \mathrm{~cm}^{-1}$ and in $\mathbf{L 1 - C u}$ at $1738 \mathrm{~cm}^{-1}$. This indicating that the coordination has taken place through oxygen of $\mathrm{C}=\mathrm{O}$ group. In $\mathbf{L} 2$, the coordination of metals seems to take place with nitrogen atom adjacent to carbonyl group as it is shown by lower absorption bands of $\mathrm{NH}$ and increasing the absorption of carbonyl to $1701 \mathrm{~cm}^{-1}$ in L2-Fe, $1681 \mathrm{~cm}^{-1}$ for L2-Ni and $1699 \mathrm{~cm}^{-1}$ for $\mathbf{L 2 - C u}$. 
The coordination of $\mathbf{L} 3$ with metals seems most probably occurred with the nitrogen of the ring neighboring to $\mathrm{C}=\mathrm{S}$ group. The blue shift in $\mathrm{C}=\mathrm{S}$ vibration $1467 \mathrm{~cm}^{-1} \rightarrow 1490 \mathrm{~cm}^{-1}$ (L3-Fe and L3-Ni) suggesting that mesmerism phenomenon is seized between nitrogen and $\mathrm{C}=\mathrm{S}$ group. The coordination between $\mathbf{C u}$ and $\mathbf{L 3}$ is most likely happened with sulphur atom. The bands present between $455 \mathrm{~cm}^{-1} \rightarrow 491 \mathrm{~cm}^{-1}$ assigned to $\gamma(\mathrm{N}-\mathrm{M})$ vibrations ${ }^{32-34}$.

\section{Biological activity}

The filter paper disk method (NCCLS) ${ }^{22-24}$ was employed in duplicate for the in vitro study of antimicrobial effects against three Gram-positive bacteria Y.p.tuberculoses, Staphylococcus aureus ATCC 25923 and Enterococcus faecalis ATTC 29212, two Gram-negative bacteria Escherichia coli ATCC 25924 and Pseudomonas aeruginosa ATCC 2783 and fungus C. albicans. DMSO was used as negative control, Ampicillin and Gentamycin were used as positive control. The inhibitory effects are summarized in Table 3.

Table 3. Antimicrobial Activity of compounds 2-6

\begin{tabular}{cccccccc}
\hline Compounds* & \multicolumn{9}{c}{ Antibacterial Activity } & \multicolumn{2}{c}{$\begin{array}{c}\text { Antifungal } \\
\text { activity }\end{array}$} \\
\hline & & $Y . p . t u b e r c u l o s e s$ & S.aureus & E.faecalis & E. coli & P.aeruginosa & C.albicans \\
\cline { 2 - 7 } Ampicillin & +++ & +++ & +++ & +++ & +++ & ++ \\
Gentamycin & +++ & ++ & +++ & +++ & +++ & ++ \\
2 & + & + & + & + & + & + \\
3 & + & + & + & + & + & + \\
4 & + & + & + & + & ++ & + \\
5 & + & + & + & ++ & ++ & ++ \\
6 & + & ++ & + & ++ & +++ & ++ \\
\hline
\end{tabular}

Concentration $10 \mathrm{mg} \mathrm{mL}^{-1 *}$ Key to the inhibition zones activities. Highly active $(+++) \geq 12 \mathrm{~mm}$. moderately active $(++) \geq 9 \mathrm{~mm}$. Slightly active $(+) \geq 6 \mathrm{~mm}$. Inactive $(-) \leq 6 \mathrm{~mm}$

The ester $\mathbf{2}$ and the hydrazide $\mathbf{3}$ showed a weak antibacterial and antifungal activity against all Gram-positive and Gram-negative bacteria as well as C.albicans under study. The oxadiazole 4 showed a moderate activity against Gram-negative $P$. aeruginosa. The $\mathrm{N}$-aminotriazolethiol 5 exhibited a wider range activity against Gram-negative E. coli, $P$. aeruginosa and fungus $C$. albicans. In another hand the double headed $N$-nucleoside 6 have shown a similar anti-microbial activity as compound $\mathbf{5}$ except on $P$. aeruginosa where its activity was rather weak.

Table 4. Inhibition of microorganisms by compounds 2-6 at minimum concentrations

\begin{tabular}{ccccccc}
\hline $\begin{array}{c}\text { Compounds, } \\
\mu \mathrm{g} \mathrm{mL}^{-1}\end{array}$ & Y.p.tuberculoses & \multicolumn{3}{c}{ Antibacterial Activity } & $\begin{array}{c}\text { Antifungal } \\
\text { activity }\end{array}$ \\
\hline 2 & 5.0 & 5.0 & 5.0 & 5.0 & 5.0 & 5.0 \\
3 & 5.0 & 5.0 & 5.0 & 5.0 & 5.0 & 5.0 \\
4 & 5.0 & 5.0 & 5.0 & 5.0 & 2.5 & 2.5 \\
5 & 5.0 & 5.0 & 5.0 & 2.5 & 2.5 & 2.5 \\
6 & 5.0 & 2.5 & 5.0 & 2.5 & 1.25 & 2.5 \\
\hline
\end{tabular}

The minimum inhibition concentration (MIC) (see Table 4) showed that the ester 2 and the hydrazide 3 had no effect on all tested microorganisms at $5.0 \mu \mathrm{g} \mathrm{mL}{ }^{-1}$ concentration. Compound 4 exhibited an anti bacterial activity against P.aeruginosa and anti fungal activity against $C$. albicans down to concentration $2.5 \mu \mathrm{g} \mathrm{mL}{ }^{-1}$. Compound 5 showed some 


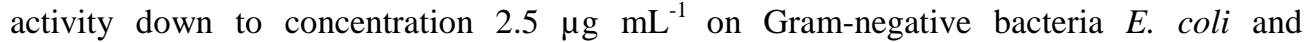
$P$. aeruginosa and fungus $C$. albicans. While compound $\mathbf{6}$ showed activity against Grampositive $S$. aureus and Gram-negative E. coli and fungus $C$. albicans down to concentration $2.5 \mu \mathrm{g} \mathrm{mL}{ }^{-1}$. However compound 6 showed its antibacterial activity upon Gram-negative bacteria $P$. aeruginosa down to concentration $1.25 \mu \mathrm{g} \mathrm{mL}^{-1}$.

\section{Conclusion}

Double headed nucleosides have significant enhancement of potency against Gram-negative bacteria and to less extent against Gram-positive bacteria and fungus in comparison with the other derivatives. The UV-Vis and IR spectroscopy are still effective tools for detecting the formation of organo-metallic complexes.

\section{Acknowledgment}

The authors express their sincere thank to Professor Ezzat A. Kadous of the Department of Chemistry, Alexandria University, Alexandria, Egypt for antimicrobial tests, to Mrs. T. Taghi and Miss S. Rihani for technical assistant.

\section{References}

1 Who, Food Additives: Food Additives Series, No.12, 1977.

2 Rao Y, Chen Q, Dong J and Qian W, Analyst, 2011, 136, 769-774.

3 Gold H and Zahm W, J Am Pharm Assoc., 1943, \&, 173-178.

4 Addington W R, Stephens R E, Gilliland K and Miller S P, Amer J Physical Medicine \& Rehabilitation, 1998, 77, 523-526.

5 Salgado J M, Rodriguez N, Cortés S and Dominguez J M, J Sci Food Agric., 2010, 90(13), 2168-2177.

$6 \quad$ Kinoshita E, Ozawa Y and Aishima T, J Agric Food Chem., 1997, 45, 3753-3759.

7 Jacques J, Collet A and Wilen S H, Enantiomers, Racemates and Resolutions, New York, Wiley and Sons, 1981.

8 Ilmarinen K, Kriis K, Paju A, Pehk T and Lopp M, Proc Estonian Acad Sci Chem., 2001, 50(3), 147-155.

9 Nemak K, Acs M, Jaszay Z, Kozma D and Fogassy E, Tetrahedron, 1996, 52, 1637-1642.

10 Casba K, Zoltan J, Jozsef B, Elemer F and David K, Tetrahedron, 2000, 56, 8355-8359.

11 Mc Cann M, Polyhedron, 1997, 16(20), 3655-3661.

12 Tan B, Zhai Z, Luo G S and Wang J D, Sci China Ser B-Chem., 2008, 51(9), 887-892.

13 Balkadi M and Othman A A, Trends Applied Sci Res., 2011, 6(1), 17-30.

14 Benhammadi S, Othman A A, Derdour A and Mami A, Asian J Chem., 2010, 22(7), 5535-5542.

15 Khiati Z, Othman A A and Guessas B, S Afr J Chem., 2007, 60, 20-24.

16 Mernari B, Elattari H, Traisnel M, Bentiss F and Langrenée M, Corros Sci., 1998, 40, 391- 399.

17 Bentiss F, Langrenée M, Traisnel M and Hornez J C, Corros Sci., 1999, 41, 789- 803.

18 Khiati Z, Othman A A, Sanchez-Moreno M, Bernard M-C, Joiret S, Sutter E M M and Vivier V, Corros Sci., 2011.

19 Kanthiah S, Kalusalingam A, Velayutham R, Vimala A T and Beyatricks J, Int J Pharm Sci Rev Reas., 2011, 6(1), 64-67.

20 Awad L F and El Ashry E S H, Carbohydr Res., 1998, 312, 9-22. 
21 Dos Anjos J V, Sinou D, de Melo S J and Srivasava R M, Carbohydr Res., 2007, 342, 2440-2449.

22 Dallal M M S, Doyle M P, Rezadehbashi M, Dabiri H, Sanaei M, Modarresi S, Bakhtiari R, Sharifiy K, Taremi M, Zali M R and Sharifi-Yazdi M K, Food Control, 2010, 21, 388-392.

23 Clinical and Laboratory Standards Institute, Performance Standards for Antimicrobial Susceptibily Testing; Sixteenth International Supplement, 2006, 26, 11-35.

24 National Committee for Clinical and Laboratory Standards Villanova, PA,,Methods for Dilution Antimicrobial Susceptibility Tests for Bacteria that Grow Aerobically, 4/e, 1997.

25 Kanthiah S, Kalusalingam A, Velayutham R, Vimala A T and Beyatricks J, International J Pharm Sci Rev Res., 2011, 6(1), 64-67.

26 Lodeiro C, Basitida R, Bertolo E, Macias A and Rodriguez R, Transition Met Chem., 2003, 28(4), 388-394.

27 Matulkova I, Némec I, Teubner K, Némec P and Micka Z, J Mol Struct., 2008, 873, 46-60.

28 Kumar G, Kumar D, Devi S, Kumar A and Johari R, E- J Chem., 2010, 7(3), 813-820.

29 Bakalbassis E G, Korabik M, Michailides A, Mrozinski J, Raptopoulou C, Skoulika S, Terzis A and Tsaousis D, J Chem Soc Dalton Trans., 2001, 850-857.

30 Belford R L, Calvin M. and Belford G, J Chem Phys., 1957, 26, 1165-1174

31 Dolaz M and Tumer M, Transition Met Chem., 2004, 29, 516-522.

32 Shakir M, Nasman O S M and Varkey S P, Polyhedron, 1996, 15, 309-314.

33 Shakir M, Islam K S, Mohamed A K, Shagufa M and Hasan S S, Transition Met Chem., 1999, 24, 577-580.

34 Chandra S and Kumar R, Transition Met Chem., 2004, 29, 269-275. 